\title{
Processing of coconut sap into sugar syrup using rotary evaporation, microwave and open-heat evaporation techniques
}

\begin{abstract}
Background: Coconut sugar has a caramel color with a taste like brown sugar. It is commonly used as natural sweetener. However, coconut sugar has been produced from coconut sap using a traditional method that involves heating the sap at high temperature $\left(>100{ }^{\circ} \mathrm{C}\right)$ in an open pan for a long period $(3-5 \mathrm{~h})$. This conventional method results in an over-cooked sugar, which leads to quality deterioration in terms of both its physical and chemical properties. The current study aimed to investigate the processing of coconut sap into sugar syrup using alternative processing techniques such as rotary vacuum evaporation (RE) and microwave evaporation (ME), comparing them with open-heat evaporation (OHE) technique. Results: Coconut sugar syrup produced by rotary evaporation at $60^{\circ} \mathrm{C}$ and 250 mbar vacuum (RE-60) required the shortest production time $(12.2 \mathrm{~min})$ and the lowest processing temperature $\left(54.8^{\circ} \mathrm{C}\right)$ when compared with $\mathrm{ME}\left(13 \mathrm{~min}\right.$ and $\left.103.2^{\circ} \mathrm{C}\right)$ and $\mathrm{OHE}\left(46.8 \mathrm{~min}\right.$ and $\left.101.6^{\circ} \mathrm{C}\right)$. It also had a light brownish color with a higher $\mathrm{L}^{*}$ value (35.17) than the ME (29.84) and OHE (23.84) methods. It was found to contain higher amounts of monosaccharides (fructose and glucose) and lower amounts of disaccharides (sucrose). Furthermore, the amount of energy required for RE-60 $(0.35 \mathrm{kWh})$ was much less than for OHE $(0.83 \mathrm{kWh})$. Conclusion: This study provided an alternative processing method for the sugar processing industry to produce coconut sugar using the rotary evaporation method at $60{ }^{\circ} \mathrm{C}$ under 250 mbar vacuum with better physicochemical qualities, shorter processing time, and minimum input energy.
\end{abstract}

Keyword: Ultra-high molecular weight polyethylene; Cellulose nanofiber; Bionanocomposite; Response surface methodology; Optimization; Melt-blend processing 